\title{
PENDIDIKAN GIZI MELALUI PENINGKATAN PENGETAHUAN TENTANG KEAMANAN MAKANAN JAJANAN ANAK SEKOLAH Fitri Mairizki ${ }^{1}$, Rika Mianna ${ }^{2)}$ \\ 1)Program Studi Ilmu Keperawatan, STIKes Al-Insyirah Pekanbaru \\ 2)Program Studi Kesehatan Masyarakat, STIKes Al-Insyirah Pekanbaru \\ Email: fitri_mairizki@yahoo.com
}

\begin{abstract}
ABSTRAK
Kebiasaan jajan pada anak sudah menjadi kebiasaan umum dan ditemui diberbagai tingkat sosial ekonomi masyarakat. Makanan jajanan anak sekolah banyak dijumpai di lingkungan sekolah dan rutin dikonsumsi sebagian besar anak usia sekolah khususnya anak usia sekolah dasar karena harganya yang terjangkau dan sebagai tambahan asupan energi. Namun, peranan makanan jajanan yang strategis ini belum diimbangi dengan mutu dan nilai gizi yang diharapkan. Oleh karena itu, tim dosen dari STIKes AlInsyirah perlu untuk melakukan kegiatan pengabdian masyarakat terkait dengan masalah tersebut. Solusi yang ditawarkan oleh tim adalah melakukan kegiatan penyuluhan tentang kandungan zat-zat berbahaya dalam makanan jajanan di lingkungan sekolah dan dampaknya bagi kesehatan, penyuluhan dan demonstrasi tentang kebiasaan mencuci tangan sebelum makan serta pemberian susu kepada siswa sebagai salah satu contoh jajanan sehat. Dengan pelaksanaan kegitan ini, siswa diharapkan dapat mengetahui jenis makanan jajanan yang berpotensi mengandung zatzat makanan berbahaya dan memahami dampaknya sehingga sekolah dapat membuat kebijakan terkait makanan jajanan di sekolah dalam rangka menjaga kesehatan para siswa.
\end{abstract}

Kata kunci: makanan jajanan, zat-zat makanan berbahaya, jajanan sehat

\section{ABSTRACT}

Snacking habits in children have become common habits and found in various levels of socio-economic community. School children's snacks are often found in the school environment and routinely consumed by most school-age children, especially elementary school-aged children because of their affordable price and additional energy intake. However, the strategic roles of the snacks are not yet balanced with the quality and nutritional value that expected. Therefore, the team of lecture from AlInsyirah School of Health needs to carry out community service activities related to the problem. The solution offered by the team is conducting counseling about the content of harmful substances in snack foods in the school environment and their impact on health, counseling and demonstrations about the habit of washing hands before eating and giving milk to students as an example of healthy snacks. With the implementation of this activity, students are expected to be able to find out the types of snacks that have the potential to contain hazardous food substances and understand their impact so that the school can make policies related to snack foods in school in order to maintain the health of students.

Key words: snack foods, dangerous food substances, healthy snacks 


\section{PENDAHULUAN}

Kebiasaan jajan pada anak sudah menjadi kebiasaan umum dan ditemui diberbagai tingkat sosial ekonomi masyarakat. Pada umumnya, anak-anak sekolah dasar lebih suka makanan jajanan dibandingkan makanan berat. Mereka membeli makanan jajanan di kantin sekolah maupun pedagang kaki lima (PKL) di sekitar sekolah. Makanan jajanan berfungsi sebagai makanan yang pertama kali masuk ke saluran pencernaan bagi anak yang tidak terbiasa makan pagi sehingga pada sebagian anak makanan jajanan menjadi penting artinya (Yulianingsih, Pratiwi, 2009).

Makanan jajanan anak sekolah dasar sangat beragam jenisnya. Makanan jajanan yang kebersihannya tidak dapat dikontrol oleh pihak sekolah serta tercemar oleh debu dan kotoran yang mengandung telur cacing, bakteri atau mikroorganisme lainnya dapat menjadi sumber penularan infeksi cacingan, disentri dan penyakit infeksi lainnya pada anak. Kontaminan yang ada di tanah/debu akan sampai pada makanan jajanan tersebut jika dibawa oleh lalat ataupun angin terutama pada makanan jajanan yang tidak tertutup. Konsumsi jajanan yang tidak tepat dapat menimbulkan dampak negatif bagi anak. Dampak negatif yang ditimbulkan diantaranya diare, kekurangan zat gizi, dan gangguan pertumbuhan seperti stunting (Hartono, N.,P., Catur, S.,W., dan Sri A, 2015).

Selain kontaminasi mikrobiologis, kontaminasi kimiawi yang umum ditemukan pada makanan jajanan kaki lima adalah bahan tambahan pangan (BTP) seperti boraks (mengandung logam berat boron), formalin (pengawet mayat), rhodamin $B$ (pewarna merah pada tekstil), dan methanil yellow (pewarna kuning pada tekstil) (Lestari, T., P., Lystiani H., dan Shoim D., 2011). Penyalahgunaan bahan-bahan kimia berbahaya sebagai bahan tambahan bagi produk makanan dapat memberikan warna makanan yang menarik, tekstur makanan yang kenyal, makanan yang tahan lama, serta harga yang terjangkau sehingga dianggap mampu menarik minat anak sekolah untuk berbelanja (Irawan, I.,N.,A.,S., dan Luh, S.,A., 2016). Bahan-bahan tersebut dapat terakumulasi pada tubuh manusia dan bersifat karsinogenik yang dalam jangka panjang menyebabkan penyakit seperti kanker dan tumor pada organ tubuh manusia. BTP dapat juga mempengaruhi fungsi otak termasuk gangguan perilaku pada anak sekolah. Gangguan perilaku tersebut meliputi gangguan tidur, gangguan konsentrasi, gangguan emosi, gangguan bicara, hiperaktif hingga memperberat gejala pada penderita autis. Penggunaan BTP dalam jangka pendek dapat menimbulkan gelaja-gejala yang sangat umum seperti pusing, mual, muntah, diare dan susah buang air besar (Judarwanto, W., 2011).

Laporan kinerja Badan Pengawas Obat dan Makanan (BPOM) pada tahun 2013, BPOM sudah mampu menurunkan jumlah persentase PJAS yang tidak memenuhi syarat dengan hasil uji PJAS dari tahun 2010 sampai 2013 mengalami peningkatan yaitu $55,52 \%$ menjadi 80,79\% yang memenuhi syarat. Pada tahun 2014 terjadi penurunan PJAS yang memenuhi syarat dibandingkan tahun 2013, yaitu 76,18\% dari $90 \%$ yang ditargetkan. Data Kejadian Luar Biasa (KLB) keracunan pangan yang dihimpun oleh Direktorat Surveilan dan Penyuluhan Keamanan Pangan-BPOM RI dari Balai Besar/Balai POM di seluruh Indonesia menunjukkan bahwa 17,26-25,15\% kasus terjadi di lingkungan sekolah dengan kelompok tertinggi siswa sekolah dasar (BPOM RI, 2014).

Sekolah dan penjual makanan jajanan hampir tidak bisa dipisahkan. Kebiasaan siswa yang cenderung selalu jajan di sekolah menyebabkan di setiap sekolah selalu banyak terdapat penjual makanan jajanan. Penjual makanan jajanan tersebut ada yang 
permanen berbentuk warung/toko dan ada pula yang tidak permanen seperti menggunakan sepeda, sepeda motor, gerobak dorong atau gerobak pikul. Para penjual makanan jajanan selalu ramai oleh siswa pada setiap jam istirahat maupun pulang sekolah. Namun, sekolah belum mempunyai kebijakan khusus terkait makanan jajanan tersebut sehingga para siswa dapat secara bebas membeli makanan jajanan di lingkungan sekolah, baik yang ada di kantin sekolah atau di luar sekolah (Purwani, Eni, Ambarwati, A.P., Santoso, 2013).

Dari hasil wawancara dengan Kepala Sekolah SD N 160 Pekanbaru diketahui bahwa pihak sekolah sudah berusaha untuk mengarahkan para siswa agar berbelanja di kantin sekolah yang menjual makanan jajanan yang lebih sehat dan lebih aman. Namun, sebagian besar siswa masih lebih suka membeli makanan jajajan yang dijual oleh PKL di luar sekolah karena menu makanan jajanan yang lebih bervariasi dan tampilan makanan yang lebih menarik.

Salah satu upaya yang dapat dilakukan untuk mengatasi permasalahan di atas adalah dengan melakukan usaha edukasi keamanan makanan jajanan kepada siswa sekolah. Kegiatan ini penting dilakukan karena anak usia sekolah adalah golongan yang memerlukan perhatian dalam konsumsi makanan dan zat gizi. Tumbuh dan berkembangnya anak usia sekolah yang optimal tergantung pemberian nutrisi dengan kualitas dan kuantitas yang baik serta benar. Anak sekolah pada umumnya berada dalam masa pertumbuhan yang sangat cepat dan aktif, pengaturan makanan yang bergizi baik, seimbang dan beraneka ragam jenis akan memastikan kecukupan gizinya (Harfines, P., P., dan Fithia, D.,P., 2017). Oleh karena itu, dibutuhkan suatu metode pendidikan gizi untuk meningkatkan pengetahuan tentang makanan jajanan yang sehat dan bergizi pada anak. Dengan pemberian penyuluhan kepada siswa sekolah dasar diharapkan dapat menimbulkan kesadaran siswa akan bahaya jajan sembarangan serta melakukan perilaku-perilaku yang sehat untuk tidak jajan sembarangan dan dapat mengedukasi teman-temannya untuk melakukan perilaku yang sama.

Dalam rangka mengatasi kebiasaan jajan sembarangan pada anak sekolah dasar, diperlukan kerjasama yang baik dari berbagai pihak termasuk pemerintah, sekolah, orang tua, kalangan medis dan juga akademisi. Pemerintah berperan dalam membantu pembiayaan pengadaan fasilitas kantin sekolah dan membuat peraturan-peraturan untuk menunjang keamanan pangan di sekolah dasar. Pihak sekolah dan orang tua berperan dalam memberikan pengawasan, bimbingan dan pengarahan kepada para siswa agar dapat memilih, membeli dan mengonsumsi makanan yang mempunyai nilai gizi dan aman dikonsumsi. Kalangan medis dan akademisi juga diharapkan dapat berperan penting dengan memberikan penyuluhan tentang bahaya jajan sembarangan kepada pihak sekolah, orang tua dan juga siswa. Kerjasama yang baik dari semua pihak ini diharapkan dapat mengatasi permasalahan kebiasaan jajan sembarangan pada anak sekolah dasar sehingga dengan pemberian nutrisi yang terjamin kualitas dan kuantitasnya akan dapat meningkatkan kualitas generasi penerus bangsa Indonesia.

\section{TINJAUAN PUSTAKA}

\section{Makanan Jajanan}

Pangan adalah segala sesuatu yang berasal dari sumber hayati produk pertanian, perkebunan, kehutanan, perikanan, peternakan, dan perairan baik yang diolah maupun tidak diolah yang diperuntukkan sebagai makanan atau minuman bagi manusia, termasuk bahan tambahan pangan, bahan baku pangan, dan bahan lainnya yang digunakan dalam proses penyiapan, pengolahan, dan pembuatan 
makanan atau minuman. Salah satu contoh pangan yang sering digunakan manusia adalah makanan jajanan. Menurut Food and Agriculture Organization (FAO), makanan jajanan atau street food adalah makanan dan minuman yang dipersiapkan dan dijual oleh pedagang kaki lima di jalanan dan di tempat-tempat keramaian umum lain yang langsung dimakan atau dikonsumsi tanpa pengolahan atau persiapan lebih lanjut. Keunggulan makanan jajanan adalah murah, mudah didapat, rasanya enak dan cocok dengan selera sebagian besar masyarakat. Ada empat kelompok makanan jajanan yaitu makanan utama/main dish, makanan panganan/snack, minuman dan buah-buahan segar (Noorhamdani dkk., 2011).

Makanan jajanan (street food) sudah menjadi bagian yang tidak terpisahkan dari kehidupan masyarakat, baik di perkotaan maupun dipedesaan. Badan Pusat Statistik (2004) menunjukkan bahwa perilaku jajan lebih banyak ditemui di daerah perkotaan (90\%) daripada di pedesaan (78\%). Hal ini dimungkinkan karena semakin sempitnya waktu bagi keluarga di kota besar untuk menyiapkan makanan minuman sendiri (Noorhamdani dkk., 2011).

\section{Bahan Tambahan Pangan}

Bahan tambahan pangan (BTP) adalah bahan yang ditambahkan dengan sengaja ke dalam makanan dalam jumlah kecil dengan tujuan untuk memperbaiki penampakan, cita rasa, tekstur dan memperpanjang daya simpan. Selain itu, juga dapat meningkatkan nilai gizi seperti protein, mineral dan vitamin (Widyaningsih dan Murtini, 2006).

Menurut Peraturan Menteri Kesehatan RI No.722/Menkes/Per/IX/1988, BTP adalah bahan yang biasanya tidak digunakan sebagai makanan dan biasanya bukan merupakan ingredient khas makanan, mempunyai atau tidak mempunyai nilai gizi yang dengan sengaja ditambahkan ke dalam makanan untuk maksud teknologi (temasuk organoleptik) pada pembuatan, pengolahan, penyiapan, perlakuan, pengepakan, pengemasan, penyimpanan atau pengangkutan makanan untuk menghasilkan atau diharapkan menghasilkan (langsung atau tidak langsung) suatu komponen atau mempengaruhi sifat khas makanan tersebut (Budiyanto, 2001).

Penggunaan BTP dalam proses produksi pangan perlu diwaspadai bersama, baik oleh produsen maupun oleh konsumen. Dampak penggunaannya dapat berakibat positif maupun negatif bagi masyarakat. Penyimpangan dalam penggunaannya akan membahayakan, khususnya generasi muda sebagai penerus pembangunan bangsa. Di bidang pangan, diperlukan pangan yang lebih baik untuk masa yang akan datang, yaitu pangan yang aman untuk dikonsumsi, lebih bermutu, bergizi dan lebih mampu bersaing dalam pasar global. Kebijakan keamanan pangan (food safety) dan pembangunan gizi nasional (food nutrient) merupakan bagian integral dari kebijakan pangan nasional, termasuk pengunaan BTP (Cahyadi, 2008).

\section{Jenis Bahan Tambahan Pangan}

Pada umumnya BTP dibagi menjadi dua bagian besar, yaitu :

a. Aditif sengaja : yaitu aditif yang diberikan dengan sengaja dengan maksud dan tujuan tertentu, misalnya untuk meningkatkan konsistensi, nilai gizi, cita rasa, mengendalikan keasaman atau kebasaan, memantapkan bentuk atau rupa dan lain sebagainya. 
b. Aditif tidak sengaja, yaitu aditif yang terdapat dalam makanan dalam jumlah sangat kecil sebagai akibat dari proses pengolahan.

Bila dilihat dari asalnya, aditif dapat berasal dari sumber alamiah seperti lesitin, asam sitrat, dan lain sebagainya, dapat juga disintesis dari bahan kimia yang mempunyai sifat serupa dengan bahan alamiah yang sejenis, baik susunan kimia maupun sifat metabolismenya seperti misalnya $\beta$-karoten, asam askorbat, dan lain-lain. Pada umumnya bahan sintetik mempunyai kelebihan yaitu lebih pekat, lebih stabil, dan lebih murah. Walaupun demikian ada kelemahannya yaitu sering terjadi ketidaksempurnaan proses sehingga mengandung zat-zat yang berbahaya bagi kesehatan, dan kadang-kadang bersifat karsinogenik yang dapat merangsang terjadi kanker pada hewan atau manusia (Winarno, 1992).

BTP yang diizinkan untuk digunakan pada makanan berdasarkan Permenkes No.722/Menkes/Per/IX/1988 adalah (Fardiaz, 2007) :

a. Anti oksidan dan oksidan sinergis, yaitu BTP yang digunakan untuk mencegah terjadinya proses oksidasi. Contoh : asam askorbat dan asam eritrobat serta garamnya untuk produk daging, ikan dan buah-buahan kaleng; butilhidroksi anisol (BHA) atau butilhidroksi toluen (BHT) untuk lemak, minyak dan margarin.

b. Anti kempal, yaitu BTP yang dapat mencegah menggempalnya makanan yang berupa serbuk, tepung atau bubuk. Contoh : Ca silikat, Mg karbonat, dan Si dioksida untuk merica dan rempah lainnya; garam stearat dan tri Ca fosfat pada gula, kaldu dan susu bubuk.

c. Pengatur keasaman, yaitu BTP yang dapat mengasamkan, menetralkan, dan mempertahankan derajat keasaman makanan. Contoh: Asam laktat, sitrat, dan malat digunakan pada jeli; natrium bikarbonat, karbonat, dan hidroksida digunakan sebagai penetral pada mentega.

d. Pemanis buatan, yaitu BTP yang dapat menyebabkan rasa manis pada makanan yang tidak atau hampir tidak mempunyai nilai gizi. Contoh : sakarin dan siklamat.

e. Pemutih dan pematang tepung, yaitu BTP yang dapat mempercepat proses pemutihan tepung dan atau pematangan tepung hingga dapat memperbaiki mutu penanganan.

f. Pengemulsi, pemantap dan pengental, yaitu BTP yang dapat membantu terbentuknya atau memantapkan sistem dispersi yang homogen pada makanan, biasa digunakan untuk makanan yang mengandung air atau minyak. Contoh: polisorbat untuk pengemulsi es krim dan kue; pektin untuk pengental pada jamu, jeli, minuman ringan dan es krim; gelatin pemantap dan pengental untuk sediaan keju, karagenen; dan agar-agar untuk pemantap dan pengental produk susu dan keju.

g. Pengawet, yaitu BTP yang dapat mencegah fermentasi, pengasaman atau penguraian lain terhadap makanan yang disebabkan oleh mikroorganisme, biasa ditambahkan pada makanan yang mudah rusak atau yang disukai sebagai medium pertumbuhan bakteri atau jamur. Contoh : asam benzoat dan garamnya, ester para hidroksi benzoat untuk produk buah-buahan, kecap, keju dan margarin; asam propionat untuk keju dan roti.

h. Pengeras, yaitu BTP yang dapat memperkeras atau mencegah lunaknya makanan. Contoh : Al sulfat, Al Na sulfat untuk pengeras pada acar ketimun dalam botol; Ca glukonat dan Ca sulfat pada buah kaleng seperti tomat dan kaleng. 
i. Pewarna, yaitu BTP yang dapat memperbaiki atau memberi warna pada makanan. Contoh : karmin, ponceau 4R, eritrosin warna merah; green FCF, green S warna hijau; kurkumin, karoten, yellow kuinolin, tartazin warna kuning; dan karamel warna coklat.

j. Penyedap rasa dan aroma serta penguat rasa, yaitu BTP yang dapat memberikan, menambahkan atau mempertegas rasa dan aroma. Contoh : monosodium glutamat pada produk daging.

k. Sekuestran, yaitu BTP yang dapat mengikat ion logam yang ada pada makanan sehingga dicegah terjadinya oksidasi yang dapat menimbulkan perubahan warna dan aroma, biasa ditambahkan pada produk lemak dan minyak atau produk yang mengandung lemak atau minyak seperti daging dan ikan. Contoh : asam folat dan garamnya.

BTP yang tidak diizinkan atau dilarang digunakan dalam makanan menurut Permenkes RI No.1168/Menkes/Per/X/1999 adalah :

a. Natrium tetraborat (boraks)

b. Formalin (formaldehyd)

c. Minyak nabati yang dibrominasi (brominated vegetable oils)

d. Kloramfenikol (chloramphenicol)

e. Kalium klorat (potassium chlorate)

f. Dietilpirokarbonat (diethylepirokarbonate DEPC)

g. Nitrofurazon (nitrofurazone)

h. P-Phenetilkarbamida ( $p$-phenethycarbamide, dulcin, 4-ethoxyphenyl urea)

i. Asam salisilat dan garamnya (salicylic acid andm its salt)

j. Rhodamin B (pewarna merah)

k. Methanil yellow (pewarna kuning)

1. Dulsin (pemanis sintesis)

m. Potasium bromat (pengeras)

\section{METODE PELAKSANAAN}

Metode yang digunakan dalam kegiatan pengabdian masyarakat ini adalah ceramah dan demonstrasi. Ceramah digunakan untuk memberikan pengetahuan tentang kandungan zat berbahaya dalam makanan jajanan di lingkungan sekolah dan dampaknya bagi kesehatan. Demonstrasi digunakan untuk memberikan pengetahuan tentang cara mencuci tangan yang baik dan benar serta contoh jajanan sehat yang bergizi.

Tahap-tahap dalam kegiatan pengabdian masyarakat ini adalah sebagai berikut : (a) Perencanaan dan persiapan, pada tahap ini tim pelaksana berkoordinasi dengan pihak mitra mengenai peserta, waktu, tempat dan susunan acara kegiatan. (b) Sosialisasi kegiatan, kegiatan ini bertujuan untuk memberikan pengumuman kepada peserta kegiatan tentang penyuluhan yang akan dilaksanakan. Kegiatan sosialisasi dilakukan oleh pihak mitra sebagai salah satu bentuk kontribusi dalam pelaksanaan kegiatan pengabdian masyarakat. (c) Penyuluhan, kegiatan ini dilakukan dengan pemberian materi menggunakan media power point kepada para siswa. Materi yang disampaikan yaitu tentang definisi makanan jajanan, faktor-faktor yang mempengaruhi anak jajan, zat-zat berbahaya yang terkandung dalam makanan jajanan dan dampaknya bagi kesehatan serta tips aman memilih jajanan sehat. (d) Demonstrasi, kegiatan ini dilakukan dengan pemutaran video dan praktek kepada para siswa tentang cara mencuci tangan yang baik dan benar serta pemberian susu kepada para siswa sebagai contoh 
makanan jajanan. (e) Evaluasi kegiatan, kegiatan ini bertujuan untuk mengetahui tingkat keberhasilan dari kegiatan. Parameter keberhasilan dari kegiatan ini adalah meningkatnya pengetahuan peserta kegiatan tentang jajanan sehat. Evaluasi kegiatan dilaksanakan dengan memberikan pertanyaan-pertanyaan tentang materi yang telah disampaikan kepada peserta kegiatan.

\section{HASIL DAN PEMBAHASAN}

Kegiatan pengabdian masyarakat di SD N 160 Pekanbaru dilaksanakan untuk memberikan pengetahuan kepada siswa tentang berbagai jenis makanan jajanan yang berpotensi mengandung zat-zat makanan berbahaya dikonsumsi dan dampak yang ditimbulkannya. Peserta kegiatan adalah guru dan siswa kelas V yang berjumlah 60 orang.

Kegiatan pengabdian masyarakat ini dilaksanakan pada tanggal 12 November 2016 dengan rincian sebagai berikut : (1) Pembukaan dan pengarahan dari sekolah, kegiatan ini merupakan acara seremonial yang dihadiri oleh kepala sekolah, perwakilan guru dan tim pengabdian masyarakat dari STIKes Al-Insyirah Pekanbaru. Acara seremonial yang utama adalah kata sambutan dari pihak sekolah yang berisi tentang arahan dan harapan dari kegiatan pengabdian. (2) Ceramah, kegiatan ini adalah pemberian materi tentang keamanan makanan jajanan kepada siswa dalam bentuk ceramah dan paparan menggunakan media power point. Isi ceramah sesuai dengan tema kegiatan yaitu tentang definisi makanan jajanan, faktor-faktor yang mempengaruhi anak jajan, zat-zat berbahaya yang terkandung dalam makanan jajanan dan dampaknya bagi kesehatan serta tips memilih jajanan sehat. Kegiatan ini diakhiri dengan diskusi dan memberikan kesempatan kepada para siswa untuk bertanya terkait materi yang telah disampaikan. (3) Demonstrasi, kegiatan ini merupakan pemutaran video oleh mahasiswa STIKes Al-Insyirah Pekanbaru tentang enam langkah mencuci tangan dan dilanjutkan dengan praktek langsung kepada para siswa tentang cara mencuci tangan yang baik dan benar. Kegiatan diakhiri dengan pemberian susu kepada para siswa sebagai contoh makanan jajanan. (4) Evaluasi, kegiatan ini dilakukan dengan memberikan pertanyaan kepada peserta seputar materi yang telah diberikan. Kegiatan ini bertujuan untuk mengetahui pemahaman peserta tentang materi jajanan sehat. Peserta juga diminta untuk mempraktekkan kembali cara mencuci tangan yang baik dan benar secara bersama-sama. (5) Pembagian doorprize, kegiatan ini adalah pemberian hadiah kepada peserta yang dapat menjawab pertanyaan dan aktif selama kegiatan dilaksanakan. Tujuan kegiatan ini adalah merangsang keaktifan peserta kegiatan dan membangun suasana kegembiraan. (6) Penutupan, kegiatan ini pemberian ucapan terimakasih oleh kepala sekolah kepada tim pengabdian masyarakat dari STIKes AlInsyirah Pekanbaru. Kegiatan ini akhiri dengan dengan pemberian kenang-kenangan kepada pihak sekolah dan foto bersama.

Secara umum, kegiatan pengabdian masyarakat ini berjalan dengan lancar dan sesuai dengan yang telah direncanakan. Jumlah peserta kegiatan juga sesuai dengan target yang diharapkan. Antusiasme peserta kegiatan terlihat dari semangat ketika mendengar dan menyimak materi penyuluhan serta ketika memberikan pertanyaanpertanyaan terkait dengan materi penyuluhan. Peserta kegiatan sangat antusias dan berpartisipasi secara aktif dalam kegiatan ini dari awal sampai akhir kegiatan. Foto-foto kegiatan dapat dilihat pada gambar 1 dan 2 . 


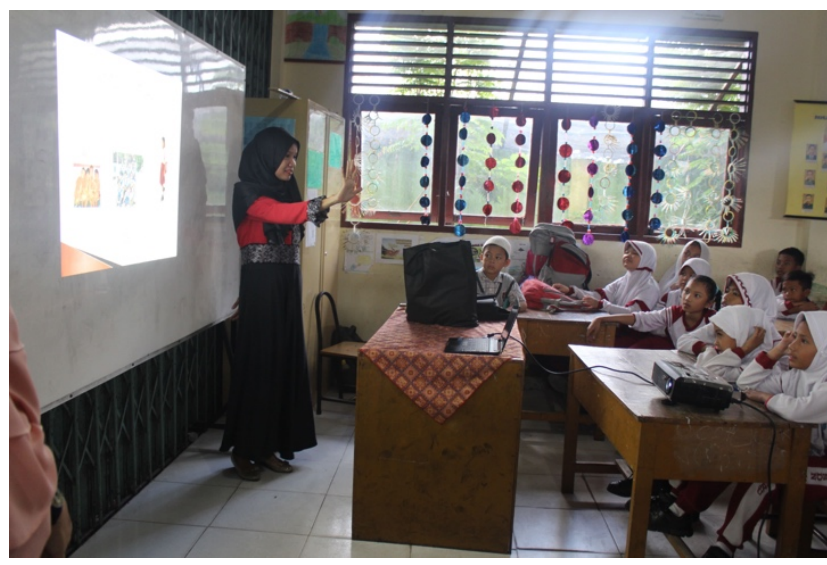

Gambar 1. Penyampaian Materi

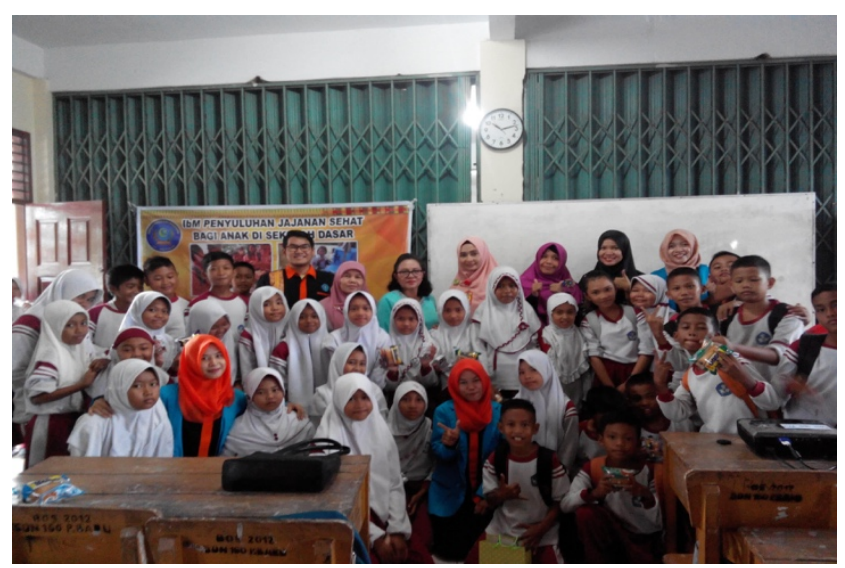

Gambar 2. Foto Bersama Peserta Kegiatan

Evaluasi hasil kegiatan dilakukan untuk mengetahui tingkat keberhasilan dari kegiatan. Evaluasi dilakukan dengan memberikan pre test dan post tes kepada siswa tentang pertanyaan-pertanyaan yang terkait materi yang diberikan. Dari hasil evalusi diketahui bahwa pengetahuan peserta tentang makanan jajajan meningkat setelah mengikuti kegiatan pengabdian masyarakat ini. Distribusi hasil pre test dan post test dapat dilihat pada tabel 1 .

Tabel 1. Distribusi Hasil Pre Test dan Pos Test

\begin{tabular}{cccccc}
\hline No. & Interval Nilai & Pre Test & Presentase (\%) & Post Test & Presentasi (\%) \\
\hline 1 & $0-10$ & 0 & 0 & 0 & 0 \\
2 & $11-20$ & 0 & 0 & 0 & 0 \\
3 & $21-30$ & 10 & 16,7 & 0 & 0 \\
4 & $31-40$ & 12 & 20 & 2 & 3,33 \\
5 & $41-50$ & 18 & 30 & 6 & 10 \\
6 & $51-60$ & 12 & 20 & 8 & 13,33 \\
7 & $61-70$ & 8 & 13,3 & 4 & 6,68 \\
8 & $71-80$ & 0 & 0 & 23 & 38,33 \\
9 & $81-90$ & 0 & 0 & 15 & 25 \\
10 & $91-100$ & 0 & 0 & 2 & 3,33 \\
\hline
\end{tabular}

Respon peserta kegiatan terhadap penyelenggaraan kegiatan adalah positif. Evaluasi terbuka dari para guru umumnya puas dengan penyelenggaraan kegiatan. Pihak sekolah ingin kegiatan seperti ini dapat berjalan secara periodik dan berpandangan bahwa kegiatan ini sangat bermanfaat baik bagi guru maupun para siswa. Indikator keberhasilan kegiatan pengabdian masyarakt dapat dilihat dilihat pada tabel 2 . 
Tabel 2. Indikator Keberhasilan Kegiatan Pengabdian Masyarakat

\begin{tabular}{|c|c|c|c|}
\hline No. & Kriteria Evaluasi & Indikator & Tolak Ukur \\
\hline 1 & $\begin{array}{l}\text { Keberhasilan } \\
\text { penyuluhan } \\
\text { tentang keamanan } \\
\text { makanan jajanan }\end{array}$ & $\begin{array}{l}\text { a. Peserta dapat mengetahui zat-zat } \\
\text { berbahaya yang terkandung dalam } \\
\text { makanan jajanan } \\
\text { b. Peserta dapat mengetahui dampak } \\
\text { zat-zat berbahaya yang terkandung } \\
\text { dalam makanan jajanan bagi } \\
\text { kesehatan serta } \\
\text { c. Peserta dapat mengetahui tips } \\
\text { memilih jajanan sehat }\end{array}$ & $\begin{array}{l}\text { Hasil berupa } \\
\text { peningkatan } \\
\text { pengetahuan } \\
\text { tentang keamanan } \\
\text { makanan jajanan }\end{array}$ \\
\hline 2 & $\begin{array}{l}\text { Keberhasilan } \\
\text { demonstrasi cara } \\
\text { mencuci tangan } \\
\text { yang baik dan } \\
\text { benar }\end{array}$ & $\begin{array}{l}\text { Peserta dapat mempraktekkan sendiri } \\
\text { cara mencuci tangan yang baik dan } \\
\text { benar }\end{array}$ & $\begin{array}{l}\text { Hasil berupa } \\
\text { peningkatan } \\
\text { pengetahuan } \\
\text { tentang } \\
\text { mencuci tangan } \\
\text { yang baik dan } \\
\text { benar }\end{array}$ \\
\hline
\end{tabular}

\section{KESIMPULAN}

Dari kegiatan yang telah dilakukan dapat disimpulkan bahwa secara umum kegiatan berjalan dengan baik dan lancar terlihat dari peserta kegiatan sangat antusias dan berpartisipasi secara aktif dalam kegiatan ini dari awal sampai akhir kegiatan. Kegiatan pengabdian ini juga telah mampu meningkatkan pengetahuan peserta kegiatan tentang keamanan makanan jajanan di sekolah.

\section{DAFTAR PUSTAKA}

[5]. BPOM RI. 2014. Laporan Kinerja Badan POM Tahun 2014. Jakarta.

[6]. Budiyanto, AK. 2001. Dasar-Dasar Ilmu Gizi. Malang. Universitas Muhammadiyah.

[7]. Cahyadi, W. 2008. Analisis dan Aspek Kesehatan Bahan Tambahan Pangan Edisi 2 Cetakan I. Jakarta. Bumi Aksara.

[8]. Fardiaz, S. 2007. Bahan Tambahan Makanan. Bogor. Institut Pertanian Bogor.

[9]. Harfines, P, P, dan Fithia, D,P. 2017. Hubungan Stunting dengan Prestasi Belajar Anak Sekolah Dasar di Daerah Kumuh, Kotamadya Jakarta Pusat. Buletin Penelitian Kesehatan, 45 (1) : 45-52.

[10]. Hartono, N.,P., Catur, S.,W., dan Sri A. 2015. Pendidikan Gizi tentang Pengetahuan Pemilihan Jajanan Sehat antara Metode Ceramah dan Metode Komik. Indonesian Journal of Human Nutrition, 2(2) : 76-84.

[11]. Irawan, I.N.A.S., dan Luh, S.A. 2016. Prevalansi Kandungan Rhodamin B, Formalin dan Boraks pada Jajanan Kantin serta Gambaran Pengetahuan Pedagang Kantin di Sekolah Dasar Kecamatan Susut Kabupaten Bangli. EJurnal Medika, 5(11) : 1-5 
[12]. Judarwanto W. 2011. Perilaku Makan Anak Sekolah. Jakarta. Direktorat Bina Gizi Kementerian Kesehatan Republik Indonesia.

[13]. Lestari, T, P, Lystiani H, dan Shoim D. 2011. Hubungan Pola Konsumsi Makanan Jajanan dengan Morbiditas dan Status Gizi Anak Sekolah Dasar di Wilayah Kartasura. Jurnal Kesehatan, 4(1) : 92-100.

[14]. Noorhamdani, A., Kusuma, T.S., dan Latifah, S.N. 2011. Analisis Kualitatif Formalin, Boraks, dan Rhodamin B pada Keamanan Pangan Kerupuk Aci, Rambak, Ikan, dan Berwarna di Pasar Tradisional Mergan dan Pasar Besar Tradisional Kota Malang.

[15]. Purwani, Eni., Ambarwati, A.P., Santoso. 2013. Peningkatan Pengetahuan dan Sikap Keamanan Makanan Jajanan Melalui Media Cerita Bergambar di Madrasah Ibtidaiyah Muhammdiyah Kabupaten Sukoharjo. Warta, 16(1) : 1-13.

[16]. Widyaningsih, T.D. dan Murtini, ES. 2006. Alternatif Pengganti Formalin Pada Produk Pangan. Jakarta. Trubus Agrisarana.

[17]. Winarno, F.G. 1992. Kimia Pangan dan Gizi. Jakarta. Gramedia Pustaka Utama.

[18]. Yulianingsih, Pratiwi. 2009. Hubungan Pengetahuan Gizi dengan Sikap Anak Sekolah Dasar dalam Memilih Makanan Jajanan di Madrasah Ibtidaiyah Tanjunganom, Kecamatan Baturetno, Kabupaten Wonogiri. Surakarta. Universitas Muhammadiyah Surakarta. 